\title{
New Zealand Coal Resources
}

\section{Introduction}

The U.S. Geological Survey (USGS), in conjunction with partners from some 50 countries, is developing an integrated electronic database of coalquality information - the World Coal Quality Inventory (WoCQI). Information is provided for samples representing prominent coal beds in all of the major coal-producing countries, as well as coals from many of the smaller producers. This Fact Sheet summarizes coal-quality and coal-resource information for New Zealand.

\section{Estimated In-Ground Resource}

Coal is New Zealand's most abundant fossil fuel and has been an important energy source since the late nineteenth century. Coal beds are present in the Northland, Waikato, and Taranaki Coal Regions of the North Island and in the Nelson, West Coast, Canterbury, Otago, and Southland Coal Regions of the South Island (fig. 1). The total in-ground resource is estimated to be 15,600 million metric tons (Mt), of which about $8,700 \mathrm{Mt}$ (56 percent) is recoverable (Barry and others, 1994). Most of the resource is in the South Island; more than 13,000 Mt (84 percent) of the in-ground coal are lignite deposits there (table 1). The North Island in-ground resource of about 2,500 Mt (16 percent) is almost entirely subbituminous coal.

\section{Coal Geology and Rank}

With the exception of a few thin beds in pre-Cretaceous strata (Suggate, 1990), all New Zealand coal beds occur within late CretaceousCenozoic sedimentary units. Coal measures commonly rest unconformably on older basement rocks, often being overlain by marine sediments. Occasionally they occur above mid-Tertiary marine beds, at the base of overlying nonmarine beds, or rarely they are interbedded within a marine sequence. Differential subsidence has led to wide variations in thermal histories that cause extreme variations in rank, sometimes over short distances.

New Zealand coal beds range in rank from high-moisture lignite to low volatile bituminous, with minor anthracite occurrences resulting from local contact metamorphism (Suggate, 1959). Lignite and subbituminous coal are most abundant, constituting over 90 percent of in-ground and recoverable resources.

\section{Coal Production and Mining Methods}

Coal production reached $1 \mathrm{Mt}$ in 1900 and $2 \mathrm{Mt}$ by 1910. Production increased at a slower rate between 1910 and 1960, when annual production reached 3 Mt. From 1960 to 1992, annual production fluctuated between $2 \mathrm{Mt}$ and $3.5 \mathrm{Mt}$, but it has exceeded $3 \mathrm{Mt}$ since 1993. Over the last 20 years, the South Island's West Coast region and the North Island's Waikato region have been the largest producers. In 1996, the West Coast region produced 49 percent of New Zealand's coal, while 41 percent was mined in the Waikato region. The Southland, central Otago, and Canterbury regions of the South Island produced 9 percent, 1 percent, and a very small quantity, respectively. Total production figures by mining method for 1999 and 2000 appear in table 2. Total cumulative production from all New Zealand coal fields to the end of 1998 was about $253 \mathrm{Mt}$ (New Zealand Ministry of Commerce, 1998a).

Before 1940, less than 10 percent of production was from opencast mines. Opencast production has increased steadily to 80 percent of current production. Of the $3.5 \mathrm{Mt}$ of coal produced in 1996, 47 percent was bituminous, 46 percent subbituminous, and 7 percent lignite. All bituminous production was from the West Coast region, and most subbituminous production was from the Waikato region, with much smaller amounts from the Southland and West Coast regions. Lignite production was from the Southland and Otago regions, with very small amounts from the Canterbury and West Coast regions (New Zealand Ministry of Commerce, 1998b).

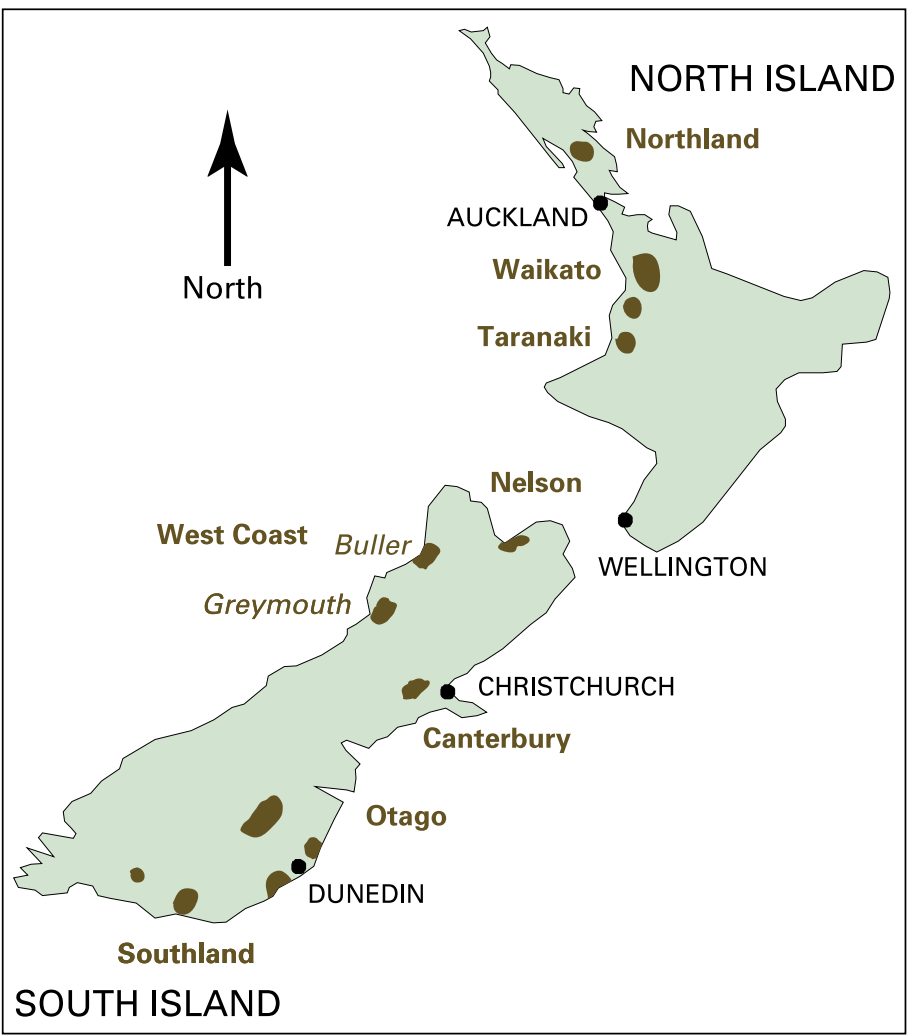

Figure 1. Major coal regions (bold brown type) and coal fields (italic brown type) of New Zealand.

\section{Unique Coal Quality}

Coal-quality parameters that make New Zealand coals unique in the world market include very low sulfur levels ( $0.25-0.35$ percent), extremely low ash yields (about 1 weight percent), and low phosphorus content $(0.005$ percent from the Stockton Mine in the Buller Coal Field). In addition, bituminous coking coals from the West Coast region of the South Island may exhibit high free swell index numbers $(9+)$ and high fluidity. All New Zealand coals exhibit high vitrinite composition, greater than 90 percent, with 95 percent common (Gillard and Moore, 1999). These characteristics allow New Zealand export coals to be used internationally as value-added products that bring coal blends into a target compositional range with the least additional volume. As a result, domestic coals that have marginal properties and other lower cost coals can be introduced into a blend or can be used to produce special products.

One consequence of the extremely low ash yields is an unusual inorganic chemical composition (Li and others, 2001). For example, 49 samples from the Buller Coal Field (fig. 1) had an average ash yield of 1.4 weight percent, with a minimum of 0.2 weight percent. For major elements in the 41 samples that had 10 weight percent ash or less, silicon and aluminum contents in the coals were commonly each less than 1,000 parts per million (ppm) on a coal basis, and calcium contents were less than $400 \mathrm{ppm}$.

On an ash basis, the chemistry of the New Zealand coals is even more unusual. One sample from the Buller Coal Field had more than 6,500 ppm nickel in the ash. Although arsenic content, in general, is low (less than $5 \mathrm{ppm}$ in the coal), several samples had more than $1,000 \mathrm{ppm}$ in the ash, and two samples had more than $10,000 \mathrm{ppm}$. Coals from the North Island Waikato region have substantially higher boron and strontium contents (both about $300 \mathrm{ppm}$ ) than do the South 
Table 1. New Zealand coal resources.

\begin{tabular}{|c|c|c|c|}
\hline Coal region & Coal rank & $\begin{array}{c}\text { In-ground } \\
\text { resource } \\
\text { (million metric } \\
\text { tons) }\end{array}$ & $\begin{array}{c}\text { Recoverable } \\
\text { resource } \\
\text { (million metric } \\
\text { tons) }\end{array}$ \\
\hline Northland & Subbituminous & 3 & - \\
\hline Waikato & Subbituminous & 2,100 & 700 \\
\hline Taranaki & Subbituminous & 380 & 170 \\
\hline \multicolumn{2}{|c|}{ Total, North Island } & 2,483 & 870 \\
\hline Nelson & Subbituminous & 2 & - \\
\hline West Coast & $\begin{array}{l}\text { Lignite, } \\
\text { subbituminous, } \\
\text { and bituminous }\end{array}$ & 980 & 340 \\
\hline Canterbury & $\begin{array}{l}\text { Lignite and minor } \\
\text { anthracite }\end{array}$ & 4 & 2 \\
\hline Otago & $\begin{array}{l}\text { Lignite and } \\
\text { subbituminous }\end{array}$ & 2,700 & 1,200 \\
\hline Southland & $\begin{array}{l}\text { Lignite and } \\
\text { subbituminous }\end{array}$ & 9,400 & 6,300 \\
\hline \multicolumn{2}{|c|}{ Total, South Island } & 13,086 & 7,842 \\
\hline
\end{tabular}

Island coals (generally less than 50 ppm boron and less than $30 \mathrm{ppm}$ strontium, except for the Southland region, which has about $200 \mathrm{ppm}$ boron). Waikato and Southland coals have 17 to 42 weight percent calcium oxide $(\mathrm{CaO})$ in the ash, whereas coals from the West Coast region have about 1 weight percent. Despite low pyritic sulfur values of 0.01-0.02 weight percent, coals from the Greymouth Coal Field in the West Coast region have the highest lead, antimony, and thallium values.

\section{New Zealand Coal Exports}

In the mid-1970s, awareness of the special qualities of New Zealand's premium-grade bituminous coals increased. Coal exports, mainly to Japan, increased steadily to about 0.5 Mt annually by 1990 . Expansion of export markets during the 1990s led to a rapid increase in exports between 1992 and 1997, peaking at 1.6 Mt (44 percent of total production) for the year ending March 1997. For the year ending March 1998, however, exports decreased by 50 percent to $0.8 \mathrm{Mt}$ ( 26 percent of total production), because of a significant decrease in exports to China, Japan, Australia, and Chile. Export volumes recovered to about 1.7 Mt in 2001. New Zealand's largest coal export markets for 1998 were Japan, India, Chile, China, Australia, and Belgium (fig. 2). Special-

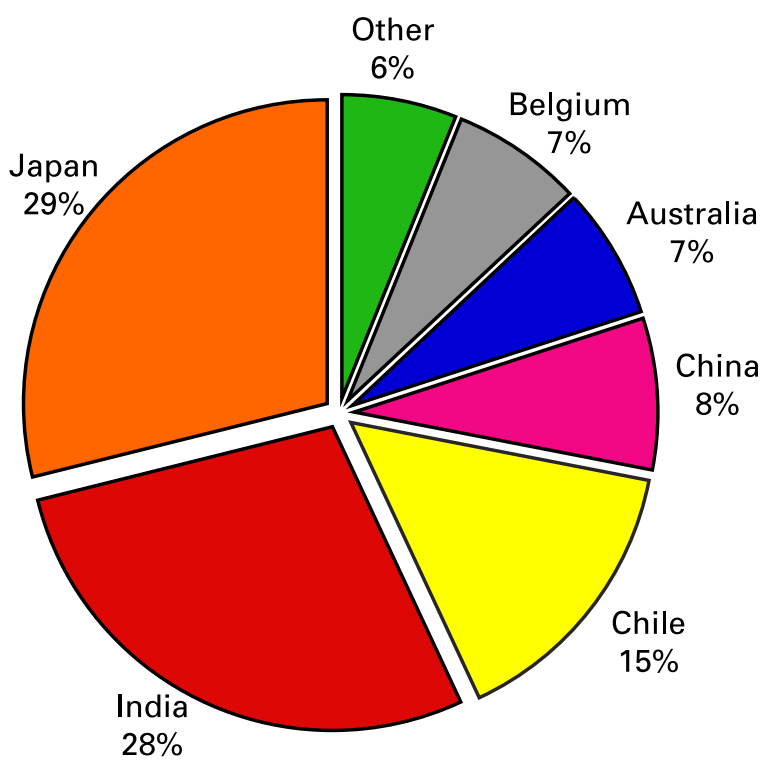

Figure 2. New Zealand coal export markets in 1998.
Table 2. New Zealand coal production.

\begin{tabular}{lcc}
\hline $\begin{array}{l}\text { Mining } \\
\text { method }\end{array}$ & $\begin{array}{c}\text { 1999 production } \\
\text { (metric tons) }\end{array}$ & $\begin{array}{c}\text { 2000 production } \\
\text { (metric tons) }\end{array}$ \\
\hline Underground & 921,100 & 884,600 \\
Opencast & $2,584,700$ & $2,701,100$ \\
Total & $\mathbf{3 , 5 0 5 , 8 0 0}$ & $\mathbf{3 , 5 8 5 , 7 0 0}$ \\
\hline
\end{tabular}

quality coal is also in demand for specialized metallurgical and other industrial processes.

\section{Future Trends}

New Zealand's coal fields have been well explored, and its coal resources are quite well defined. Currently, little exploration for new reserves is taking place, and the industry is concentrating on improving knowledge of reserves within existing license areas. This status is likely to continue for some time. Electricity generation consumes about 20 percent of New Zealand's domestic coal supply, and consumption is unlikely to increase in the future. New Zealand industry accounts for about 70 percent of domestic coal consumption, with steel manufacturing the largest customer.

Coal exporting has been the major growth area for the New Zealand coal industry since about 1990 and should continue to be a good prospect for the future. Although there has been demand for premiumquality bituminous coal, there is also a growing international market for thermal coals, such as New Zealand's lower grade bituminous and subbituminous coals.

\section{References Cited}

Barry, J.M., Duff, S.W., and MacFarlan, D.A.B., 1994, Coal resources of New Zealand: New Zealand Ministry of Commerce, Energy and Resources Division, Resource Information Report 16, 73 p.

Gillard, G.R., and Moore, T.A., 1999, New Zealand coal characteristics in the global scene: New Zealand Mining magazine, v. 25, p. 30-38.

Li, Z., Moore, T.A., and Weaver, S.D., 2001, Leaching of inorganics in the Cretaceous Greymouth coal beds, South Island, New Zealand: International Journal of Coal Geology, v. 47, p. 235-253.

New Zealand Ministry of Commerce, 1998a, New Zealand Energy Data File, July 1998: Wellington.

New Zealand Ministry of Commerce, 1998b, New Zealand Annual Mining Review 1996: Wellington.

Suggate, R.P., 1959, New Zealand coals-Their geological setting and its influence on their properties: Department of Scientific and Industrial Research Bulletin 134, 112 p.

Suggate, R.P., 1990, Coal ranks in Permian-Lower Cretaceous rocks of New Zealand: New Zealand Journal of Geology and Geophysics, v. 33, p. 163-172.

\section{By Tim A. Moore and Robert B. Finkelman}

\section{For additional information}

Tim A. Moore

Department of Geological Science

University of Canterbury

Private Bag 4800

Christchurch, NZ

E-mail: tim.moore@canterbury.ac.nz

Robert B. Finkelman

U.S. Geological Survey

956 National Center

Reston, VA 20192, U.S.A.

Telephone: (703) 648-6473

E-mail: rbf@usgs.gov 